\title{
THE PRINCIPLE OF PROPORTIONALITY AND THE BILLERUD RULING
}

\author{
Ana-Marija Čičak*
}

\begin{abstract}
Summary: The paper approaches the problematic related to the role played by the proportionality principle in the case law of the Court of Justice of the European Union, through the lens of the Billerud case. When conducting the proportionality analysis, the Court employs different standards of the examination, depending on the subject matter in question. In this sense, the paper focuses on three distinctive fields: discretionary policy choices, penalties, and fundamental rights. The paper addresses the Billerud case from all three perspectives. The Court's ruling was approached from the perspective of discretionary policy choices and was thus deprived of an in-depth proportionality examination. In this sense, the paper argues that if the case were approached from a different angle, namely from the fundamental rights perspective, it could have been ruled differently, as the Charter would have called for a stricter standard of the Court's review.
\end{abstract}

\section{Introduction}

'Acknowledging that change in the Earth's climate and its adverse effects are a common concern of humankind', the Governments of the World agreed to sign and ratify the United Nations Framework Convention on Climate Change, ${ }^{1}$ which entered into force in 1994. In order to achieve the goal of stabilising greenhouse gas emissions, the parties adopted the Kyoto protocol ${ }^{2}$ whereby they committed themselves to meet internationally binding reduction targets.

The European Union's emission trading scheme (hereinafter: EU ETS) is a system designed to approach fulfilling the Kyoto protocol's commitments in its own way. It is the biggest greenhouse gas trading scheme in the world, established by the Directive on greenhouse gas emissions

\footnotetext{
Law graduate of the Faculty of Law, University of Zagreb.

1 United Nations Framework Convention on Climate Change (adopted 9 May 1992, opened for signature 4 June 1992, entered into force 21 March 1994) 1771 UNTS 107 (UNFCCC).

2 Kyoto Protocol to the United Nations Framework Convention on Climate Change (adopted 11 December 1997, entered into force 16 February 2005) 2303 UNTS 161 (Kyoto Protocol).
} 
trading. ${ }^{3}$ In order to ensure compliance, the Directive imposes a high financial sanction in the form of an excess emissions penalty. ${ }^{4}$ The penalty has been subject to interpretation problems which led to the ruling of the Court of Justice of the European Union (hereinafter: the Court) in the Billerud $^{5}$ case, where the Court opted for the strict approach despite the invoked principle of proportionality.

A pressing issue such as climate change unquestionably deserves strict enforcement mechanisms. The EU, being a global leader in climate change policy, and putting this at the top of the list of its agendas, ${ }^{6}$ especially takes care of risks threatening the proper functioning of the EU ETS. The Billerud ruling confirms this. However, the Billerud ruling also confirms that when it comes to important policy objectives of the Union, the Court is not willing to rely on general principles in order not to undermine the achievement of the set goals. ${ }^{7}$

The focus of this paper is on the application of the principle of proportionality in the Court's case law. In order to analyse the Court's ruling in Billerud, different versions of proportionality will be considered.

In the first part of the paper, the general principle of proportionality will be considered. This part of the paper will be divided into three sections. The first will observe the Court's role in assessing the legality of EU measures brought within the discretionary powers of the EU legislator. The second section will analyse the Court's approach when assessing the proportionality of penalties imposed by EU administrative measures. The third section will assess the Court's case law on the proportionality of penalties adopted pursuant to EU legislation but provided for by national law. Afterwards, concluding remarks will be made in order to clarify the basic strands drawn from the presented case law.

The second part of the paper focuses on the Court's ruling in Biller$u d$. In order to give context, a brief overview of the EU ETS will be given. Afterwards, the Court's ruling as well as the Advocate General's Opinion

\footnotetext{
3 Directive 2003/87/EC of the European Parliament and of the Council of 13 October 2003 establishing a scheme for greenhouse gas emissions allowance trading within the Community and amending Council Directive 96/61/EC [2003] OJ L275/32 (hereinafter: EU ETS Directive or the Directive).

4 ibid, art 16(3).

5 Case C-203/12 Billerud Karlsborg AB and Billerud Skärblacka AB v Naturvårdsverket ECLI:EU:C:2013:664.

6 See Miguel Arias Cañete, Commissioner for Climate Action and Energy, 'European Union: a Global Leader in Climate Action' (Speech before the ENVI committee of the European Parliament, 12 Novembre 2014) <https://ec.europa.eu/clima/news/articles/ news_2014111202_en> accessed 10 August 2017.

7 Koen Lenaerts and José A Gutiérrez-Fons, The Constitutional Allocation of Powers and General Principles of EU Law' (2010) 47 CML Rev 1629, 1630.
} 
will be analysed. Lastly, the Billerud case will be assessed in the light of the EU Charter of Fundamental Rights. ${ }^{8}$

The aim of this paper is to explore several settings encompassing the proportionality analysis in the Court's case law. The Billerud case was ruled from the perspective of discretionary policy choices and was thus deprived of an in-depth proportionality examination. The question posed is whether the practical effects of the proportionality principle have been taken away from it by the Court's reserved approach. The paper does not intend to seek an objective answer to this question, as any attempt to do so carries a risk of subjectivity. However, in the light of the case law and observations to be presented, the paper aims to show that the Court's approach in the Billerud case did not touch upon several aspects which indicate the disproportionate nature of the penalty. It will thus be argued that if the case had been approached from a different angle, namely from the fundamental rights perspective, it could have been ruled differently, as the Charter would have called for a stricter standard of the Court's review.

'Law is a way of thinking.' ${ }^{9}$ In this sense, it could be argued that there are no value neutral judgments. Keeping this in mind, the paper merely aims to offer the author's personal opinion on the approach that should have been taken in the Billerud case.

\section{The principle of proportionality}

The proportionality principle is a general principle of law used as a method of assessing whether the means employed to achieve certain (legitimate) objectives unjustifiably impinge on other protected interests and values. It is one of the general principles of EU law and thus part of EU primary law. Consequentially, all EU secondary norms have to be in compliance therewith. In this sense, general principles serve as a tool for interpretation, normative gap filling, and judicial review. ${ }^{10}$ In regard to the latter, the proportionality principle plays an important role in the Court's adjudication, forming a general head of review of both EU measures and national measures falling within the scope of EU law. ${ }^{11}$

\footnotetext{
8 Charter of Fundamental Rights of the European Union [2012] OJ C326/391 (hereinafter: the Charter).

9 Expression borrowed from Amanda Brown, 'A Sense of Proportion: The Principle of Proportionality in the European Community' 3 New Zealand Postgraduate Law E-Journal 3 <https://cdn.auckland.ac.nz/assets /nzpglejournal/Subscribe/Documents / 2006-1/6_ amanda.pdf> accessed 10 August 2017.

10 Lenaerts and Gutiérrez-Fons (n 7) 1629.

11 Paul Craig, 'Proportionality, Rationality and Review' [2010] New Zealand Law Review 265, 270.
} 
The principle emerged from the Court's case law. Its first notion can be found in the Court's ruling from as early as the European Coal and Steal Community Treaty in the case Fédéchar $v$ High Authority. ${ }^{12}$ However, it was the Court's landmark ruling in Internationale Handelgesellschat, ${ }^{13}$ where the Court applied the principle in a clear and detailed fashion, which led to the wide application of this principle in the Court's case law. ${ }^{14}$

A version of this principle is codified in article 5(4) of the Treaty on European Union. This article denotes the institutional nature of the principle, as it regulates the relation between the Union and its Member States. ${ }^{15}$ As such, it protects Member States from excessive interferences with their competences. However, the focus of this paper is not on this aspect of the proportionality principle, but rather on its material expres$\operatorname{sion}^{16}$ regulating relations between individuals and public authorities.

The proportionality analysis comprises three separate tests. ${ }^{17}$ Each test examines the fulfilment of the specific requirement. The first test analyses whether the measure is suitable to achieve the objective pursued. In order to evaluate the appropriateness of a measure, the Court has to closely examine the objective it aims to realise. The objective must be a legitimate objective recognised by EU law. Only after this can the Court come to a conclusion whether the measure is suitable. ${ }^{18}$ If the Court finds that the measure cannot contribute to the accomplishment of the objective, the measure fails the first requirement mandated by the proportionality test, and further inquiry will not be needed. Applying the second sub-test, the Court examines the necessity of the measure. The measure will be regarded as necessary only if it achieves its aim by the least intrusive means. If the same result could have been achieved by a more lenient measure, the measure in question does not satisfy the necessity requirement. ${ }^{19}$ While this second step looks at the 'formal excessiveness ${ }^{20}$ of a measure, the following third step examines its 'substantial

12 Case 8/55 Fédération Charbonnière de Belgique v High Authority of the European Coal and Steel Community ECLI:EU:C:1956:7, 299 where the Court held that in accordance with a generally accepted rule of law such an indirect reaction by the high authority to illegal action on the part of the undertakings must be in proportion to the scale of that action', cited in Takis Tridimas, The General Principles of EU Law (2nd edn, OUP 2006) 141.

13 Case 11/70 Internationale Handelsgesellschaft mbH v Einfuhr- und Vorratsstelle für Getreide und Futtermittel ECLI:EU:C:1970:114, para 12.

14 Tridimas (n 12) 141.

15 Justyna Maliszewska, The Principle of Proportionality in the European Community Law: General Characteristic and Practical Application' (2008) 24 Pravni Vjesnik 89, 90.

16 ibid.

17 ibid, 91; Gráinne de Búrca, 'The Principle of Proportionality and its Application in EC Law' (1993) 13(1) Yearbook of European Law 105, 113.

18 ibid.

19 ibid.

20 Robert Schütze, 'EU Competences: Existence and Exercise' in Anthony Arnull and Damian Challmers (eds), The Oxford Handbook of European Union Law (OUP 2015) 100. 
excessiveness ${ }^{21}$ and is called proportionality stricto sensu. This implies a balancing activity which ensures that the advantages of achieving the objective pursued outweigh the disadvantages caused to other protected interests and rights. It protects those who are affected by a certain measure from bearing intolerable burdens for the sake of the realisation of the objective sought. ${ }^{22}$

The described analysis relates to the first dimension of the proportionality examination. The second dimension, which is of decisive importance for the final result of the test, concerns the standard of the examination. ${ }^{23}$ Namely, the outcome of the case will largely depend on the intensity of the examination. The Court does not always employ the same standard of review, as the latter varies depending on the role played by the proportionality principle in the specific subject matter. This has led to different versions of the proportionality test applied by the Court in its adjudication process. ${ }^{24}$

To understand the role this principle plays in judicial review, one must bear in mind both the role played by the Court as a judicial body and the specific role played by the Court as the guardian and the promoter of EU integration policy objectives. ${ }^{25}$ Regarding the former, as illustrated by de Búrca, ${ }^{26}$ the application of the principle of proportionality connoting the proper relationship between the means used and the objectives pursued 'could mean two different things'. ${ }^{27}$ On the one side, the Court could be seen to be performing its core judicial task. Namely, by reviewing measures on the basis of the proportionality principle, the Court safeguards legitimate interests and rights from too intrusive and unjustified measures and, in this way, gives the individuals concerned protection guaranteed by the rule of law. However, on the other side, the Court could be seen as over-stepping the boundaries of its role and interfering with legislative power if it 'conducts a general evaluation on costeffectiveness, efficacy, or relative importance of the aim of a particular measure'. ${ }^{28}$ In this sense, a distinction should be drawn between cases where the Court is asked to act on legal issues and cases relating to legislative subject matters where the Court's role becomes less legitimate. In

\footnotetext{
21 ibid.

22 In practice, the Court does not follow this formula every time. The third step, proportionality in the narrow sense, does not constitute an integral part of every court's inquiry. Paul Craig, EU Administrative Law (OUP 2006) 656-57.

23 Schütze (n 20) 99-100.

24 ibid.

25 See Dorota Leczykiewicz, 'Why Do the European Court of Justice Judges Need Legal Concepts?' (2008) 14(6) European Law Journal 773, 781.

26 de Búrca (n 17).

27 ibid 107.

28 ibid.
} 
general, the lesser impact a certain measure has on particular interests and rights, the smaller the Court's role should be in assessing the measure's validity. ${ }^{29}$

The latter role - the Court as the guardian and promoter of EU integration - is related to the former, but is shaped by the unique particularities of the setting (the EU) within which the Court exists. In this regard, it can be said that the Court is 'politically motivated' by the objectives of the EU's integration policy. In this sense, it cannot be considered as politicsproof, but rather as an actor paving the way for their realisation. ${ }^{30}$

In general, we can differentiate between cases concerning EU measures and cases relating to Member States' measures. With regard to the former, Craig further differentiates between cases concerning discretionary policy choices on the one hand, and cases concerning penalties and fundamental rights on the other. ${ }^{31}$

\subsection{Discretionary policy choices}

The Court's case law concerning the review of EU measures on the ground of the proportionality principle has mostly been related to the exercise of the discretionary policy choices by the EU legislator. ${ }^{32}$ In this regard, the Court's approach has been described as very deferential towards the legislative branch. ${ }^{33}$ Namely, the legislature must be allowed broad discretion in 'all areas which involve political, economic and social choices on its part, and in which it is called on to undertake complex assessments'. ${ }^{34}$ The Court's approach in these cases has been justified by the separation of powers doctrine - the Court, as a judicial branch, is not a democratically elected body and therefore cannot assume the role of legislator. ${ }^{35}$

Thus, the standard of review applied by the Court in these cases does not imply compliance in the full sense of the word with the requirements mandated by the proportionality analysis as noted in the previous section. The limited review involves the examination of whether the challenged measure represents a manifestly inappropriate decision made

\footnotetext{
29 ibid.

30 See n 25.

31 Craig (n 22) 655.

32 Paul Craig and Gráinne de Búrca, EU Law: Text, Cases and Materials (6th edn, OUP 2015) 552 .

33 ibid.

34 Case C-365/08 Agrana Zucker GmbH v Bundesminister für Land- und Forstwirtschaft, Umwelt und Wasserwirtschaft ECLI:EU:C:2010:27, Opinion of AG Trstenjak, para 63 and the case law cited therein.

35 de Búrca (n 17) 108; in the Court's wording: ‘(...) In its judicial review of the exercise of such powers, the Court cannot substitute its own assessment for that of the European Union legislature (...)', Billerud (n 5) para 35.
} 
by the legislator. This would mean that the Court should conduct each subtest of the proportionality examination by referring to this special criterion. ${ }^{36}$ In this sense, regarding the suitability requirement, the measure would be deemed to be unsuitable to achieve the desired outcome only if it was manifestly unsuitable. In this regard, the Court states that the legality of a measure adopted (...) can be affected only if the measure is manifestly inappropriate having regard to the objective which the competent institution is seeking to pursue'. ${ }^{37}$ As for the necessity requirement, the criterion to be applied is 'not whether the measure adopted by the legislature was the only one or the best one possible but whether it was manifestly inappropriate'. ${ }^{38}$ A measure will be manifestly inappropriate in this regard only if it manifestly goes beyond what is necessary in order to achieve the objective that is pursued. ${ }^{39}$ In regard to proportionality stricto sensu, the Court formulates the requirement using the following expression - the Court 'could, at most, find fault with its legislative choice only if (...) or if the resultant disadvantages for certain economic operators were wholly disproportionate to the advantages otherwise offered'. ${ }^{40}$ It will largely depend on the arguments put by applicants whether the Court will assess this part of the proportionality analysis. If it does, it only superficially examines this last step and generally does not provide for the substantive justifications for the conclusions made, but merely concludes that the importance of the objective sought justifies the interference with the interest concerned. ${ }^{41}$

As Advocate General Kokott explained in one of her opinions, ${ }^{42}$ the case law is not always clear enough in regard to the usage of these formulas and their practical effect. However, as she states, the bottom line is, or at least should be, that if a clearly less intrusive but equally effective measure is possible, or if a measure brought is apparently disproportionate, judicial protection should not be denied. Conversely, "the principle of proportionality, which is part of primary law, would be deprived of its practical effect'. ${ }^{43}$

\footnotetext{
36 See AG Trstenjak (n 34) para 70.

37 Case C-491/01The Queen $v$ Secretary of State for Health, ex parte British American Tobacco (Investments) Ltd and Imperial Tobacco Ltd ECLI:EU:C:2002:741, para 123; Case C-189/01 H Jippes, Afdeling Groningen van de Nederlandse Vereniging tot Bescherming van Dieren and Afdeling Assen en omstreken van de Nederlandse Vereniging tot Bescherming van Dieren $v$ Minister van Landbouw, Natuurbeheer en Visseri ECLI:EU:C:2001:420, para 82.

38 Jippes (n 37) para 83.

39 See C-358/14 Republic of Poland $v$ European Parliament and Council of the European Union ECLI:EU:C:2016:323, para 96.

40 Billerud (n 5) para 35.

41 Craig (n 22) $670-71$.

42 Case C-558/07 The Queen, on the application of SPCM SA CH Erbslöh KG, Lake Chemicals and Minerals Ltd and Hercules Inc $v$ Secretary of State for the Environment, Food and Rural Affairs ECLI:EU:C:2009:142, Opinion of AG Kokott, paras 72-74.

43 ibid, para 74.
} 
Another aspect of the proportionality inquiry often related to discretionary policy choices - when it comes to risk regulation - concerns the point in time as the point of reference for the proportionality assessment. In this regard, the Court can conduct proportionality analysis adopting either an ex ante or ex post approach. ${ }^{44}$ The latter approach allows the Court to take into consideration the emergence of new circumstances, whereas the former obliges the Court to base its decision only on the information available at the time of the adoption of the legislation in question. ${ }^{45}$ The Court mainly opts for the ex ante perspective. ${ }^{46}$ Namely, when 'the European Union legislature has to assess the future effects of legislation to be enacted although those effects cannot be accurately foreseen', the Court will decide whether the measure is manifestly inappropriate basing its finding on the information available at the time of the adoption of the relevant legislation. ${ }^{47}$ Advocators of the ex post perspective argue that the Court's ex post approach in reviewing the legislator's assessments would contribute to the concept of better regulation, which is something the EU emphasises it strives for. ${ }^{48}$ In this sense, they point out that 'the results, not the good intentions are important'. ${ }^{49}$ However, the ex post approach touches upon the sensitive subject matter of the separation of powers doctrine in the sense that it allows the Court to substitute its own judgment for that of the legislator. Nevertheless, as it is argued, if the ex post review is approached carefully, there is no reason for refusing it, as it would enable both the elimination of unwanted results and 'incentives for rigorous analyses in advance'. ${ }^{50}$

On the other side, Lenaerts ${ }^{51}$ finds that the ex ante legislative review in the form of 'process-oriented review' is the best option, as this way the Court does not 'second-guess the appropriateness of the policy choices made by the EU legislator' but rather assesses whether the legislator took into account all relevant interest in its decision making. ${ }^{52}$ In this sense, he

\footnotetext{
44 Roland Ismer and Christian von Hesler, 'Ex Post Review of Legislatorial Prognoses by the European Court of Justice: The Temporal Dimension of Rational Law-making' (2016) 4(2) The Theory and Practice of Legislation 279, 282.

45 ibid.

46 ibid.

47 See Billerud (n 5) para 37.

48 Ismer and von Hesler (n 44) 291.

49 ibid, 295.

50 ibid, 295-96.

51 Koen Lenaerts, 'The European Court of Justice and Process-oriented Review' (2012) European Legal Studies Research Papers in Law 1/2012 <www.coleurope.eu/study/european-legal-studies/research-activities/research-papers-law> accessed 10 August 2017.

52 ibid, 2-3, 15; see also Darren Harvey, 'Towards Process-Oriented Proportionality Review in the European Union' (2017) 23(1) European Public Law 93, 113: 'This is, of course, central to the perceived advantages of process-oriented review, which is said to be preferable to its traditional, merits based formulation precisely
} 
emphasises the importance of the preparatory work, such as Explanatory Memorandums and Impact Assessment Reports. ${ }^{53} \mathrm{He}$ argues that recent developments in the case law, especially in the post-Charter era, confirm the Court's focus on the strict process-oriented review approach. ${ }^{54}$

\subsection{EU measures and penalties}

Measures imposing financial penalties or other financial burdens affect individuals in a restrictive manner, as they have a negative effect on their economic situation. For this reason, the Court has been willing to conduct strict proportionality analyses in cases concerning administrative financial penalties. ${ }^{55}$ However, when it comes to discretionary policy choices, even if a challenged measure concerns a penalty charge, the Court will resort to the manifestly inappropriate test. ${ }^{56}$

In Molkergereseinchaft, a case that concerned the validity of a provision of a Commission Regulation on milk quotas, the Court held the following:

[A]ccording to its settled case-law, in order to establish (...) whether a provision of Community law complies with the principle of proportionality, it is necessary to ascertain whether the penalty exceeds what is appropriate and necessary to attain the objective pursued by the rules which have been breached. ${ }^{57}$

The Court continued by referring to the stricto sensu proportionality requirement: 'More particularly, it is necessary to ascertain (...) whether the disadvantages caused are not disproportionate to the aims pursued'. ${ }^{58}$ The applicant in the case was charged with the penalty because of the late communication of the summary of the statements indicating the quantities of milk which it had delivered. The delay was two days. ${ }^{59}$ The amount of the penalty provided for by the Regulation was fixed regardless of the length of the delay. ${ }^{60}$ Although the Court acknowledged the importance of

\footnotetext{
because it prevents the Court from intruding into the discretionary policymaking activities of the law-maker whilst still managing to hold the EU law-maker to account'.

53 Lenaerts (n 51) 8-9.

54 ibid, 15.

55 Craig (n 18) 681.

56 Craig and de Búrca (n 32) 556; see also Jacob Öberg, 'Union Regulatory Criminal Law Competence after Lisbon Treaty' in Hans-Jörg Albrecht and AAndré Klip (eds), Crime, Criminal Law and Criminal Justice in Europe: A Collection in Honour of Prof.em.dr.dr.h.c. Cyrille Fijnaut (Martinus Nijhoff Publishers 2013) 302.

57 Case C-356/97 Molkereigenossenschaft Wiedergeltingen eG v Hauptzollamt Lindau ECLI:EU:C:2000:364, para 35.

58 ibid, para 36.

59 ibid, paras 12-13.

60 ibid, para 33.
} 
the deadline for the proper functioning of the scheme in question, it held that the observance of that deadline was not absolutely indispensable for the smooth operation of the system, since short delays would not jeopardise the objective of the scheme. ${ }^{61}$ Therefore, the Court ruled that the contested provision was invalid because the financial sanction provided therein did not allow 'any account to be taken of the seriousness of the delay or of the impact which it may have on the attainment of the aim pursued by that legislation'. ${ }^{62}$

In another case concerning the validity of a measure prescribing detrimental legal consequences for non-observance of time limits set by a Commission Regulation, ${ }^{63}$ the Court came to the same conclusion. The case did not concern the penalty, but the total loss of the aid in the case where the time limit was exceeded. The Commission therefore argued that 'the measure at issue (...) should not be appraised by reference to the strict criteria of the proportionality rule applicable to penalties', by claiming that a measure may be regarded as a penalty 'only where it adversely affects an existing legal position or at least a legitimate expectation'. ${ }^{64}$ Since the applicant had only been deprived of the possibility to obtain the grant, neither its legal positions nor its legitimate expectations had been adversely affected. However, the Court stated as follows:

[T] he Court, in numerous judgments, has examined the conformity of measures adopted in the sphere of the common organizations of the market with the principle of proportionality when those measures entailed unfavourable legal consequences for traders, without requiring that the measure should adversely affect a right or a legitimate expectation. ${ }^{65}$

The facts of the case were the following. The contested article of the Regulation provided that 'persons required to submit harvest, production or stock declarations who do not submit such declarations by the dates specified in the Regulation were not to qualify for the benefit inter alia of the measures provided for preventive distillation'. ${ }^{66}$ Pursuant to the Regulation, the applicant was required to submit the declarations before 7 September. ${ }^{67}$ The applicant was late by four days and as a consequence was deprived of the aid otherwise available. ${ }^{68}$ The aim of the 7

\footnotetext{
61 ibid, para 41.

62 ibid, paras 43-44.

63 Case C-319/90 Otto Pressler Weingut-Weingrosskellerei GmbH \& Co. KG v Federal Republic of Germany ECLI:EU:C:1992:28.

64 ibid, para 9.

65 ibid, para 10.

66 ibid, para 4.

67 ibid, para 3.

68 ibid, para 5.
} 
September deadline was set for two reasons. Firstly, the date needed to be close to the end of the marketing year in order for the information to be more reliable. Secondly, it allowed national authorities to have long enough to gather, process and transmit the declarations to the Commission by the end of November. The overall aim was for the Commission to have adequate information about production and stocks in the wine sector, as this was essential for the correct implementation of intervention measures. ${ }^{69}$ Examining the structure of the scheme in question, the Court concluded that the only date which was of essential importance was the one of 10 December, as by this date the Commission had to be in a position 'to draw up the forward estimate before the beginning of each wine year'. ${ }^{70}$ The strict observance of the date of 7 September was not of crucial importance, as national authorities had a long time to communicate to the Commission a summary of the declarations. ${ }^{71}$ Therefore, the Court concluded that the contested article of the Regulation is invalid inasmuch as it excludes traders from the benefit of an aid (...) irrespective of the extent to which the time-limit of 7 September (...) is exceeded for the submission of the harvest declarations'. ${ }^{72}$ Thus, the Court is willing to conduct a strict proportionality test applied to penalties even in cases not concerning penalties stricto sensu.

In another case, Man (Sugar), ${ }^{73}$ the Court held that the provision of the Regulation in question was invalid as it penalised an infringement of an administrative nature in the same way as an infringement of a primary obligation imposed by the Regulation in question. ${ }^{74}$ The case concerned the applicant's failure to apply for an export licence within the time limits imposed by the Regulation. ${ }^{75}$ The Regulation penalised this failure in the same way as an infringement of an obligation to export, which was the primary obligation imposed by the Regulation. ${ }^{76}$ Even though the Commission claimed that this failure constituted an infringement of the same level of gravity as a breach of the obligation to export, the Court did not accept this line of argumentation. By interpreting the objective of the scheme in question, the Court concluded that the obligation to apply for an export licence within the prescribed time limit, given its pure administrative nature, could not constitute an obligation of the same importance as a primary obligation imposed by the legislation. ${ }^{77}$

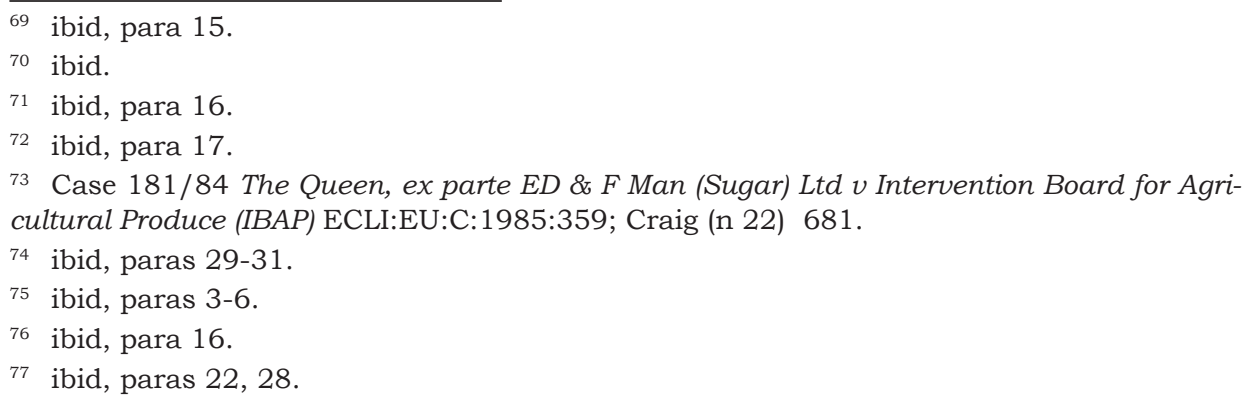


It follows that the automatic forfeiture of the entire security, in the event of an infringement significantly less serious than the failure to fulfil the primary obligation, which the security itself is intended to guarantee, must be considered too drastic a penalty in relation to the export licence's function of ensuring the sound management of the market in question. ${ }^{78}$

In this sense, it is important to differentiate between primary and secondary obligations imposed by the relevant legislation. It is not possible to penalise infringements of a secondary obligation in the same way as infringements of a primary obligation imposed by the legislation without breaching the principle of proportionality. ${ }^{79}$

The cases presented so far in this section did not concern a challenge to the discretionary policy choice nor to the measures found to be essential for the accomplishment of the objective pursued by the legislation in question. ${ }^{80}$ Regarding the latter, the Court, basing its conclusions on the importance of the objective sought by the legislation and a penalty securing the fulfilment of these objectives, ruled in favour of the challenged EU measures. Thus, as Tridimas ${ }^{81}$ pointed out, in cases such as Cereol Italia $v$ Agricola Castello ${ }^{82}$ and Fromancais $v$ Forms, ${ }^{83}$ the Court did not rely on the arguments of the applicants that it was contrary to the principle of proportionality to treat the breach of obligations they committed in the same manner as a breach of the main obligations imposed by the legislation in question. ${ }^{84}$ As the Court explained after carefully examining the objective of the schemes in question, the measures were justified taking into account their objective of preventing fraud ${ }^{85}$ and speculation, ${ }^{86}$ which was of essential importance for the proper functioning of the schemes in question. In this sense, in order to evaluate whether a measure aims to

\footnotetext{
78 ibid, 29.

79 Tridimas (n 12) 158-59.

80 In this regard, for a commentary on the Molkeregeseinschaft case, see Jacob Öberg (n 56) 307: ‘(..) the ECJ's strict review was only concerned with an implementing Commission Regulation and there was no issue of challenging the validity of the Union's legislative scheme. In my point of view this case seems, notwithstanding that it concerned the validity of Union legislation, to be concerned more with individual rights and the interests of the applicants. Since the Wiedergeltingen dairy was seriously affected by the penalty imposed by national authority and there was no essential European interest at stake, it was not surprising that the ECJ reviewed the proportionality of the measure strictly.'

81 Tridimas (n 12) 159.

82 Case C-104/94 Cereol Italia Srl v Azienda Agricola Castello Sas ECLI:EU:C:1995:313.

83 Case 66/82 Fromançais SA v Fonds d'orientation et de régularisation des marchés agricoles (FORMA) ECLI:EU:C:1983:42.

84 ibid, paras 7, 13; Cereol Italia (n 82) paras 15, 22.

85 The penalty applied only where the breach of the obligation was committed deliberately or by reason of serious negligence and in this sense was proportionate. See Cereol Italia (n 82) paras 19-25, 33.

86 Fromançais $S A$ (n 83) para 12.
} 
enforce primary or secondary obligations, special regard must be given to the objective it aims to ensure and its importance for the achievement of the objective pursued by the legislation in question. In regard to the former, as indicated above, even if the relevant measure concerns a penalty, the proportionality analysis will take the form of a manifestly disproportionate examination. Thus, in the Emsland-Stärke $G m b H^{87}$ case, a case concerning a measure providing for a penalty and falling within the scope of the legislator's discretionary policy choice, the Court applied a manifestly inappropriate proportionality test, based on which it ruled that the penalty did not contravene the proportionality principle. ${ }^{88}$

\subsection{National measures and penalties}

The case law on the proportionality of national measures concerns mostly the four freedoms and Member States' derogations therefrom. However, for the purpose of this paper attention will be given to the case law on the application of the proportionality principle in regard to the enforcement of EU law. In this context, enforcement is defined as a third stage of the implementation process. ${ }^{89}$ In order to implement EU law, Member States must transpose it, ensure its application, and finally enforce it. ${ }^{90}$ Generally, the latter presupposes a system of penalties which should ensure compliance with the obligations imposed. The Court's case law on penalties provided for by national law addresses issues related to the concept of effective, dissuasive and proportionate penalties. In regard to the latter requirement, the Court has developed a body of case law determining the standards which should be respected in order for penalties to be considered proportionate. ${ }^{91}$

According to settled case-law, in the absence of harmonisation of European Union legislation in the field of penalties applicable where conditions laid down by arrangements under that legislation are not complied with, Member States are empowered to choose the penalties which seem to them to be appropriate. They must, however, exercise that power in accordance with European Union law and its general principles, and consequently in accordance with the principle of proportionality. ${ }^{92}$

87 Case C-94/05 Emsland-Stärke GmbH v Landwirtschaftskammer Hannover ECLI: EU: C:2006:185, paras 53-59.

88 Craig and de Búrca (n 32) 556.

89 Karsten Engsig Sørensen, 'Member States' Implementation of Penalties to Enforce EU Law: Balancing the Avoidance of Enforcement Deficits and the Protection of Individuals' (2015) 40(6) European Law Review 811.

90 ibid.

91 See ibid, 813-14.

92 Case C-210/10 Márton Urbán v Vám- és Pénzügyőrség Észak-alföldi Regionális Parancsnoksága ECLI:EU:C:2012:64, para 23. 
A measure imposing a penalty complies with the proportionality principle if it is appropriate and necessary for attaining the objective pursued by the relevant legislation and if the disadvantages caused are not disproportionate to the aimed objectives. ${ }^{93}$ In this regard, the proportionality analysis is characterised by the strict standard of review.

In Urbán, a case concerning a national measure imposing a penalty adopted pursuant to a regulation on road safety, the Court specified that:

Member States are required to comply with the principle of proportionality not only as regards the determination of factors constituting an infringement and the determination of the rules concerning the severity of fines, but also as regards the assessment of the factors which may be taken into account in the fixing of a fine. ${ }^{94}$

The challenged measure provided for both strict liability and a flat rate fine applicable to several offences, not of the same level of severity. ${ }^{95}$ The applicant committed a minor offence but was ordered to pay a high fine. ${ }^{96}$ The Court stated that the fact that national authorities could not take into account the specific circumstance of the case and if necessary reduce the amount of fine was contrary to the principle of proportionality. ${ }^{97}$ In regard to the offence committed by the applicant, the Member State could have adopted a less restrictive measure, since the objective of the legislation in question, ie road safety, was not adversely affected. ${ }^{98}$ The Court also found that the disadvantages caused were not in proportion to the aim pursued, as the fine amounted almost to the average monthly net income in the Member State concerned. ${ }^{99}$ Reaching a final conclusion, the Court held that the principle of proportionality precluded a system of penalties which provides for the imposition of a flat-rate fine for all breaches, no matter how serious, of the rules in question. ${ }^{100}$ It also explained that the imposition of a system of strict liability was not in itself contrary to the principle of proportionality. ${ }^{101}$ However, the requirement of proportionality precludes the severity of the penalty provided for by that system. ${ }^{102}$

\footnotetext{
93 ibid, para 24.

94 ibid, para 54.

95 ibid, para 19.

96 ibid, paras 29, 32.

97 ibid, para 55.

98 ibid, para 57.

99 ibid, para 58.

100 ibid, para 60.

101 ibid, paras 48, 59.

102 ibid, para 59.
} 
In SC Total Waste Recycling $S R L,{ }^{103}$ a case concerning the shipment of waste, the Court was asked whether the principle of proportionality precluded the imposition of the same fine in cases concerning illegal shipment of waste as in cases concerning a breach of the requirement to obtain consent for shipment and to give prior notification in writing. ${ }^{104}$

The applicant transposing the waste which was subject to consent and to prior notification was penalised because the crossing point of entry into the Member State in question was different from the one stated in the consent and the prior notification and because he failed to inform the competent authorities of the change. The applicant argued that this was due to a breakdown in communication with the driver, who decided to enter the Member State at another crossing point, since this was a closer route to his home. The authorities qualified this as an illegal shipment and charged the applicant with a heavy fine. ${ }^{105}$ The Court stated that:

[I]n order to assess whether the penalty in question is consistent with the principle of proportionality, account must be taken inter alia of the nature and the degree of seriousness of the infringement which the penalty seeks to sanction and of the means of establishing the amount of the penalty. ${ }^{106}$

The Court further held that the national court, when reviewing the proportionality of the penalty, must take into account the objective of ensuring a high level of protection of the environment and human health which the Regulation, based on which the penalties were imposed, aims to achieve. In this regard, it must particularly take into account the risks to the environment and human health that may appear from the infringement in question. ${ }^{107}$ In this sense, the imposition of the same penalty in the case of the illegal shipment of waste as in the case of an infringement of the requirement to obtain consent and to give prior notification may be in compliance with the proportionality principle only if it can be concluded that these two breaches involve equally serious infringements. ${ }^{108}$

\subsection{Concluding remarks}

The Court's reasoning in the case law presented in the above section is similar to the Court's reasoning in cases involving a proportionality review of EU measures imposing fines, where the Court differentiates

\footnotetext{
${ }^{103}$ Case C-487/14 SC Total Waste Recycling SRL v Országos Környezetvédelmi és Természetvédelmi Főfelügyelőség ECLI:EU:C:2015:780.

104 ibid, para 50.

105 ibid, paras 21-23.

106 ibid, para 53.

107 ibid, para 55.

108 ibid, para 56.
} 
between primary and secondary obligations imposed by the relevant legislation. It could be said that in both groups of cases, the Court, by conducting the proportionality analysis, gives special regard to the principle of equality, although it does not explicitly mention it. Namely, the principle of equality mandates that different situations should not be treated equally unless it is objectively justified to treat them the same. ${ }^{109}$ By ruling that the infringements of a secondary obligation imposed by relevant legislation cannot be penalised in the same way as infringements of primary obligations, as well as by ruling that the same flat rate fine cannot be applied to infringements of different levels of severity, or that two different infringements of the relevant legislation can be penalised in the same way only if they endanger in an equally serious manner the objective pursued by the legislation in question, the Court applies basically the same concept as the one deriving from the principle of equality.

Thus, taking into account the case law presented so far, the conclusion that can be made is that when it comes to challenging penalties on the ground of the proportionality principle, judicial review is generally 'appraised by reference to the strict criteria of the proportionality rule'. ${ }^{110}$ The intensity of the review allows the Court to make an in-depth examination of all the factors concerned. This is the approach taken by the Court when assessing both EU administrative measures and national measures adopted to enforce relevant EU legislation.

When it comes to discretionary policy choices, the Court's approach is impacted by its deference towards the legislative branch. Judicial review takes the form of a manifestly inappropriate examination of a legislative measure. Thus, if a penalty is part of a discretionary policy choice, the judicial review will be deprived of 'the strict criteria of the proportionality rule applicable to penalties'. ${ }^{11}$

\section{EU ETS - overview}

The EU ETS is a market-oriented system designed to combat climate change in a cost-effective way. It was established by the EU ETS Directive in 2003. The scheme has been implemented through several trading periods. It began with a 'learning by doing' phase, which took place from 2005 to 2007 . This was followed by the second phase which lasted from 2008 to 2012 and which was marked by the introduction of the aviation

\footnotetext{
${ }^{109}$ See Joined Cases C-402/07 and C-432/07 Christopher Sturgeon, Gabriel Sturgeon and Alana Sturgeon $v$ Condor Flugdienst GmbH (C-402/07) and Stefan Böck and Cornelia Lepuschitz $v$ Air France SA ECLI:EU:C:2009:716, para 48.

${ }^{110}$ See $\mathrm{n} 64$.

111 ibid.
} 
sector in the scheme. Currently, the EU ETS is in its third stage, which will end in 2020.112 In 2015, the Commission introduced the legislative proposal for the revision of the EU ETS for the fourth phase, which will take place from 2021 to $2030 .{ }^{113}$

Each phase has brought about significant changes to the scheme for the purpose of enlarging its scope and improving its functioning. Today, the scheme applies to more than 11,000 power stations and industrial plants in 28 EU Member States, ${ }^{114}$ as well as in Iceland, Liechtenstein and Norway. ${ }^{115}$ Broadening its scope to the aviation sector, the scheme covers flights from airlines operating within the territory of the mentioned countries. ${ }^{116}$ In total, it covers approximately $45 \%$ of EU greenhouse gas emissions. ${ }^{117}$

The functioning of the scheme is based on the following logic. It is formed on a cap and trade mechanism. This means that there is an overall cap on the emissions that can be emitted by the covered participants which can trade between themselves with tradable emissions allowances within the limits of the cap. Operators are required to obtain allowances in order to emit. One allowance gives the right to emit one tonne of carbon dioxide equivalent. Operators emitting fewer than the allowances held can sell the excess of their allowances, whereas operators emitting more than permitted can buy the missing number of allowances from operators selling them. The idea is that the number of allowances available drops over time and that this stimulates companies to invest in green

112 Commission, 'EU ETS Handbook' (2015) 4 <https://ec.europa.eu/clima/sites/clima/ files/docs/ets_handbook_en.pdf> accessed 30 July 2017.

${ }^{113}$ Commission, 'Proposal for a directive of the European Parliament and of the Council amending Directive 2003/87/EC to enhance cost-effective emission reductions and lowcarbon investments' COM (2015) 337 final.

114 The United Kingdom will leave the EU on 29 March 2019, which will reduce the number of Member States to 27. See 'Brexit' <https://europa.eu/european-union/about-eu/ countries/member-countries/unitedkingdom_en\#brexit> accessed 18 November 2017. For the implications of Brexit on the EU ETS, see Thomas L Muinzer, 'An Evaluation of the Implications of EU Climate and Energy Governance for the UK in Light of Brexit' (2017) 23(2) European Journal of Current Legal Issues <http://webjcli.org/article/view/564/752> accessed 18 November 2017.

${ }^{115}$ Commission, 'Impact Assessment accompanying the document "Proposal for a Directive of the European Parliament and of the Council amending Directive 2003/87/EC to enhance cost-effective emission reductions and low-carbon investment" ' (Commission Staff Working Document) SWD (2015) 135 final, 15.

116 See Directive 2008/101/EC of the European Parliament and of the Council of 19 November 2008 amending Directive 2003/87/EC so as to include aviation activities in the scheme for greenhouse gas emission allowance trading within the Community [2008] OJ L8/3; and Decision No 377/2013/EU of the European Parliament and of the Council of 24 April 2013 derogating temporarily from Directive 2003/87/EC establishing a scheme for greenhouse gas emission allowance trading within the Community [2013] OJ L113/1.

117 SWD (2015) 135 final (n 115). 
technologies. ${ }^{118}$ The aim is to lower emissions covered by the system by $21 \%$ by 2020 (compared to 2005). By 2030, the goal is to decrease emissions by $43 \%$ (compared to 2005). ${ }^{119}$

In order to achieve this ambitious goal, it was important to put in place an effective compliance system. This was envisaged through the establishment of an annual compliance cycle of monitoring, reporting and verification of emissions and surrendering of allowances. ${ }^{120}$ In this regard, the operators are obliged to comply with the following. Firstly, operators need to hold a permit, which allows them to carry out activities covered by the Directive. ${ }^{121}$ They are then obliged to monitor and report their emissions. ${ }^{122}$ These reports have to be verified. ${ }^{123}$ Lastly, operators are required to surrender allowances covering their emissions by 30 April of the current year for the preceding year. This is the final stage preceding the cancellation of allowances. ${ }^{124}$

Member States were required to establish the system of penalties in order to ensure the enforcement of these obligations. However, the Directive itself provides for the excess emissions penalty. Article 16 of the Directive, forming the legal basis for the penalties, in the first trading period, ${ }^{125}$ stated as follows:

1. Member States shall lay down the rules on penalties applicable to infringements of the national provisions adopted pursuant to this Directive and shall take all measures necessary to ensure that such rules are implemented. The penalties provided for must be effective, proportionate and dissuasive. Member States shall notify these provisions to the Commission by 31 December 2003 at the latest, and shall notify it without delay of any subsequent amendment affecting them.

2. Member States shall ensure publication of the names of operators who are in breach of requirements to surrender sufficient allowances under Article 12(3).

3. Member States shall ensure that any operator who does not surrender sufficient allowances by 30 April of each year to cover its emissions during the preceding year shall be held liable for the

\footnotetext{
118 Commission, 'The EU Emissions Trading System (EU ETS)' < https://ec.europa.eu/clima/sites/clima/files/factsheet_ets_en.pdf> accessed 30 July 2017.

119 SWD (2015) 135 final (n 115).

120 See Commission, 'Evaluation of the EU ETS Directive: Carried out within the project "Support for the Review of the EU Emissions Trading System"' (2015) 177-78.

${ }^{121}$ EU ETS Directive, art 4.

122 ibid, art 14.

123 ibid, art 15.

124 ibid, art 12.

125 The paper refers to this period as it is the relevant period for the Billerud case. For the current version of Article 16, see the consolidated version of the EU ETS Directive at <https://ec.europa.eu/clima/policies/ets_en\#tab-0-1> accessed 30 July 2017.
} 
payment of an excess emissions penalty. The excess emissions penalty shall be EUR 100 for each tonne of carbon dioxide equivalent emitted by that installation for which the operator has not surrendered allowances. Payment of the excess emissions penalty shall not release the operator from the obligation to surrender an amount of allowances equal to those excess emissions when surrendering allowances in relation to the following calendar year.

4. During the three-year period beginning 1 January 2005, Member States shall apply a lower excess emissions penalty of EUR 40 for each tonne of carbon dioxide equivalent emitted by that installation for which the operator has not surrendered allowances. Payment of the excess emissions penalty shall not release the operator from the obligation to surrender an amount of allowances equal to those excess emissions when surrendering allowances in relation to the following calendar year.

\section{The Billerud case - general remarks}

The Billerud case concerned the interpretation and the judicial review of the excess emissions penalty. Two Swedish companies, the Billerud companies, failed to surrender, before 30 April 2007, a number of allowances equal to their emissions for the preceding year. ${ }^{126}$ Consequently, the relevant Swedish authorities imposed on them the excess emissions penalty amounting to EUR 433,120 for one company and EUR 1,697,320 for the other. ${ }^{127}$ They challenged the penalty before the national court by arguing that article 16(3) and (4) of the Directive should not have been applied, as both companies had held a sufficient number of allowances on their accounts, and so had not over-emitted. They claimed that the failure to surrender allowances happened because of an internal administrative breakdown, meaning the failure was not led by an intent to circumvent the obligations imposed by the Directive. As the first-instance court did not rule in their favour, the case ended up before the Swedish Supreme Court which commenced a preliminary ruling procedure by referring two questions to the Court. ${ }^{128}$

The first question concerned the interpretation of the aim pursued by article 16(3) of the Directive. The national court asked whether the concept of punishable emissions related to excessive polluting conduct per se, or whether the penalty meant to penalise the simple failure to surrender the allowances, no matter what the reason for non-surrender was. ${ }^{129}$

\footnotetext{
126 Billerud (n 5) para 17.

127 ibid, para 18.

128 ibid, paras 19-20.

129 ibid, paras 20-22.
} 
The answer to this question was of crucial importance to determine the proper legal basis for the imposition of the penalty in the described situation. This, in turn, was of decisive importance for the application of the proper version of the proportionality test. Thus, if the excess emissions penalty was interpreted as having the objective of penalising only excessively polluting, then the proper legal basis in the given case would have been article 16(1) of the Directive. Namely, Article 16(1) of the Directive is the proper legal basis for all penalties concerning the infringements of the provisions of the Directive which are not covered by article 16(3) of the Directive. As article 16(1) of the Directive leaves it for Member States to design the system of penalties which must be effective, proportionate and dissuasive, the Court would have dealt with a national measure enforcing EU law, and the applicable case law would have concerned a group of cases dealing with the compliance of a national measure (imposing penalties to enforce EU law) with the proportionality principle. However, if the excess emissions penalty is to be seen as applying to situations such as the one at hand, then the case concerns an EU measure brought within the legislator's discretionary policy choice, which leads to the application of a mild version of a manifestly disproportionate proportionality examination. The Court opted for the latter.

Answering the first question, it ruled that the excess emissions penalty must be understood as applying to all situations of non-surrender, no matter what reason lies behind it. ${ }^{130}$ Moving on to the second question, the Court examined the compliance of the excess emissions penalty with the proportionality principle. This examination was limited in two regards. Firstly, the Court applied the manifestly inappropriate standard of review, and, secondly, the review was performed in the form of the ex ante legislative assessment. In the light of those principles, the Court concluded that the penalty could not be considered as infringing the principle of proportionality. ${ }^{131}$

It is worth noting that the legal advisor to the Court in this case, Advocate General Mengozzi, came to different conclusions regarding the interpretation of article 16(3). ${ }^{132}$ These different interpretations led to different versions of the proportionality analyses that were conducted on the basis of the same factual situation. Namely, the least restrictive means test and the manifestly inappropriate test applied in the Advocate General's Opinion and the Court's ruling, respectively. Consequently, two proportionality tests resulted in different outcomes. The same penalty was found to be both in compliance with the proportionality principle

\footnotetext{
130 ibid, paras 30, 32 .

131 ibid, paras 34-38.

132 Case C-203/12 Billerud Karlsborg AB and Billerud Skärblacka AB v Naturvårdsverket ECLI:EU:C:2013:320, Opinion of AG Mengozzi.
} 
(the Court's ruling) and to be infringing the proportionality principle (the AG's Opinion). This is an interesting situation, as it shows how different standards of the proportionality inquiry can lead to a different final result.

\subsection{The Court's ruling - interpretation and judicial review of the excess emissions penalty}

Interpreting the excess emissions penalty, the Court ruled as follows:

Article 16(3) and (4) of Directive ... must be interpreted as precluding operators who have not surrendered, by 30 April of the current year, the carbon dioxide equivalent allowances equal to their emissions for the preceding year, from avoiding the imposition of a penalty for the excess emissions for which it provides, even where they hold a sufficient number of allowances on that date. ${ }^{133}$

Although recognising the protection of the environment as the ultimate objective pursued by the Directive, the Court stressed that the Directive did not itself reduce the emissions but aimed at securing the said goal by promoting the emissions reductions at the lowest cost through the scheme it had established. ${ }^{134}$ Since the scheme is based on the strict accounting of the issue, the holding, transfer and cancellation of allowances, and since allowances need to be surrendered in order to be cancelled, the surrender obligation must be applied with particular force. It relied on article 12(3) of the Directive and linked it directly to article 16(3). 135 The former article states the following:

Member States shall ensure that, by 30 April each year at the latest, the operator of each installation surrenders a number of allowances equal to the total emissions from that installation during the preceding calendar year as verified in accordance with Article 15, and that these are subsequently cancelled.

As for the high amount of the penalty, the Court only stated that by introducing a predefined penalty, the legislator 'wished to shield the allowance trading scheme from distortions of competition resulting from market manipulations'. ${ }^{136}$

The second question, as posed above, concerned the judicial review of the excess emissions penalty. However, the question was not phrased

\footnotetext{
133 Billerud (n 5) para 32.

134 ibid, para 26.

135 ibid, paras 25, 27.

136 ibid, para 27.
} 
in this way directly. The national court asked whether the penalty must be interpreted as meaning that its amount can be varied or even waived on the basis of the principle of proportionality, depending on the circumstances of the particular case. ${ }^{137}$ The Court answered in the negative. This was justified in the following way. The introduction of the EU ETS was a legislative choice that was made having in mind the fulfilment of the commitments made by the EU and its Member States under the Kyoto Protocol. It was based on highly complex economic and technical considerations. The EU legislator had thus engaged itself in so-called risk regulation, where it had to consider the future, uncertain effects of its action'. The excess emissions penalty, being the only penalty harmonised by the Directive, plays a vital role in ensuring the proper functioning of the EU ETS. Since forming part of a discretionary policy choice as well as of risk regulation, an examination of its compliance with the proportionality principle needed to be undertaken under the limitations imposed by both the manifestly inappropriate standard of review and an ex ante legislative evaluation. ${ }^{138}$

The Court explained that the surrender obligation, together with the lump sum penalty enforcing it, was viewed:

as necessary in the pursuit of the legitimate objective of establishing an efficient carbon dioxide equivalent allowance trading scheme, in order to prevent certain operators or market intermediaries from being tempted to circumvent or manipulate the scheme by speculating abusively on prices, quantities, time limits or complex financial products which tend to come about in any market. ${ }^{139}$

The high amount of the penalty was justified by the need to treat the infringement of this core obligation in a serious and harmonised way. ${ }^{140}$ The penalty was also justified by the fact that the operators had sufficient time to prepare themselves for the surrender obligation. ${ }^{141}$ Finally, the Court concluded that in view of the accurate accounting of the scheme, the penalty calculated pursuant to EUR 40 per allowance not surrendered did not constitute disproportionate disadvantages when compared to the environmental benefits deriving from the fulfilment of the European Union's commitments under the Kyoto protocol. ${ }^{142}$ Therefore, the Court ruled that the penalty must be interpreted 'as meaning that the

\footnotetext{
137 ibid, paras 20, 33. This question was posed as an alternative, just in case the Court interpreted the excess emissions penalty as applying to situations such as the one at hand, as it did.

138 ibid, paras 34-38.

139 ibid, para 39.

140 ibid.

141 ibid, para 40.

142 ibid.
} 
amount of the lump sum penalty provided for therein may not be varied by a national court on the basis of the principle of proportionality' and as such, in the light of the principles governing the Court's judicial review in this case, cannot be considered as contrary to it. ${ }^{143}$

\subsection{The Advocate General's Opinion - the other way}

Contrary to the Court's ruling, the Advocate General came to the following conclusion:

Article 16(3) and (4) of Directive ... must be interpreted as meaning that it does not cover the situation of an infringement of the obligation to surrender by an operator who actually has a sufficient number of allowances on 30 April of the relevant year to cover its emissions during the preceding year and who is not responsible for any pollution above the permitted amount. ${ }^{144}$

Comparing the two interpretations, one can notice that the Advocate General, by emphasising the aspect of responsibility regarding pollution, directly relies on the objective of environmental protection. Even though he acknowledged the importance of accurate accounting, ${ }^{145}$ he emphasised that the wording used in article 16(3) - that the penalty applies to 'any operator who does not surrender sufficient allowances ... to cover its emissions during the preceding year'146 - supported the finding that the excess emissions penalty meant to penalise, as its name also indicates, emissions not covered by allowances. ${ }^{147}$

Apart from leaning on the literal analysis of article 16(3), the Advocate General also conducted a teleological interpretation based on the Explanatory Memorandum of the proposal for the Directive. ${ }^{148}$ In order to explain the purpose of the penalty, he referred to the part of the Memorandum which states that the objective of article 16(3) is to ensure that 'the penalties for non-compliance are sufficiently high to ensure that it makes no sense for an operator not to go out and buy from the market a sufficient number of allowances to cover the installation's actual emissions'. ${ }^{149}$ In this sense, he also emphasised that the amount of penalty

\footnotetext{
143 ibid, paras 38, 42.

144 AG Mengozzi (n 132) para 32.

145 ibid, paras $21,27$.

146 ibid, para 28.

147 ibid, para 25.

148 Commission, 'Proposal for a Directive of the European Parliament and of the Council establishing a scheme for greenhouse gas emission allowance trading within the Community and amending Council Directive 96/61/EC' COM (2001) 581 final, Explanatory Memorandum.

149 ibid, point 17; AG Mengozzi (n 132) para 29.
} 
was set having regard to the predicted market price of the allowances. ${ }^{150}$ Accordingly, it seems that the penalty was particularly designed to economically stimulate operators to obtain a sufficient number of allowances, as the cost of non-compliance would otherwise be too high. The Advocate General thus explained that since in situations such as the one in question the operators obtained a sufficient number of allowances, they fell outside the scope of the objective that article 16 (3) aimed to ensure. ${ }^{151}$

The Advocate General also drew attention to article 16(2) which provides for a 'naming and shaming' penalty. This penalty applies together with the excess emissions penalty. He underlined that this penalty would only make sense if it was applied solely to operators committing excessive pollution. ${ }^{152}$

Placing the imposition of the penalty in the given case under the scope of article 16(1), the Advocate General invoked the Court's case law on the proportionality of penalties imposed by national measures pursuant to the EU legislation. The Advocate General particularly referred to the Court's ruling in Urbán due to the similarities between these two cases. In this respect, he emphasised that the proportionality principle must also be taken into consideration when assessing the factors which may be taken into account in the fixing of a fine. ${ }^{153} \mathrm{He}$ also referred to the recitals of the Directive, which specify that the Directive respects fundamental rights and that it focuses on achieving its objective with the least possible diminution of economic development and employment. ${ }^{154}$

Stating the facts of the case, the Advocate General underlined the following. The infringement was caused by an administrative or technical failure, there were neither unauthorised emissions nor any other wrongful act (the late surrender was not caused by a proven intention to circumvent the scheme, to speculate on the market, and/or to profit in a way likely to distort competition), and the applicants tried to set right the situation shortly after the failure occurred. ${ }^{155}$ However, since the competent Swedish authority aligned the penalty for the infringement of the obligation to surrender with the penalty provided for by article 16(3) and (4) of the Directive, due to the automatic nature of the penalty, it was impossible to take into account those findings. ${ }^{156}$ In such circumstances, the penalty seems to go beyond what is necessary and seems to be disproportionate to the interference caused to the functioning of the scheme. ${ }^{157}$

\footnotetext{
150 AG Mengozzi (n 132) para 29.

151 ibid, para 30.

152 ibid, para 31.

153 ibid, paras 35-36.

154 ibid, para 37.

155 ibid, para 40.

156 ibid, paras 38, 40.

157 ibid, paras 40-42.
} 


\subsection{Considerations}

When comparing the Opinion of the Advocate General with the judgment of the Court, one can notice that the Court did not address the part of the Memorandum where the objective of the penalty was clearly stated. Besides the part of the Memorandum cited by the Advocate General, the wording used in the Memorandum's other provisions also corroborates the conclusion that article 16(1) should apply in all cases that do not relate to excessive emissions:

Other than setting the level of penalty for each tonne over-emitted, Member States shall determine and apply sanctions for breaches of the Directive that are 'effective, proportionate and dissuasive'. (...) Furthermore, the imposition of a financial penalty would not remove the obligation in the following year for the operator of the over-emitting installation to surrender allowances corresponding to the excess emissions, or the pre-determined environmental outcome of the scheme as a whole will be undermined. ${ }^{158}$

However, it also seems that the legislator identified the infringement of the obligation to surrender with the over-emitting activities based on its predicament that no bona fide operator would be penalised with the excess emissions penalty. At least, it stems so from the following explanation - 'As operators can use any of the allowances in their possession to fulfil their obligations, it is extremely unlikely that any operators acting in good faith will incur compliance penalties before the end of the period'. 159 But, as has been shown by the case of the Billerud companies, this is not something highly unlikely to happen. Therefore, it could be argued that the excess emissions penalty is problematic not only from the point of view of the principle of proportionality but also from the perspective of the principle of equality, as two different situations are being treated equally.

Comparing the situation of an operator not covering its emissions with a sufficient number of allowances with one such as in the case of the Billerud companies, the Advocate General elaborated on two different situations. Thus, he took into account the basic concept stemming from the principle of equality. In this respect, the Court held that all EU acts must be interpreted in accordance with primary law as a whole, including the principle of equal treatment, which requires that comparable situations must not be treated differently and that different situations must not be treated in the same way unless such treatment is objectively justified. ${ }^{160}$

In the ruling, this aspect was not touched upon. Considering the case law presented earlier in this paper concerning the Court's review of

\footnotetext{
${ }^{158}$ Explanatory Memorandum (n 148) point 17.

159 ibid.

160 Sturgeon (n 109).
} 
EU measures and penalties, a conclusion was drawn by suggesting that the Court justifies even severe penalties for the infringement of obligations securing the attainment of the objectives in question when those obligations aim to prevent fraud and market manipulations which would jeopardise the very functioning of the scheme in question. By ruling that the excess emissions penalty, aiming to ensure strict accounting, was necessary to penalise market manipulations and speculation which would jeopardise the very objective of the EU ETS, the Court adopted a similar line of reasoning. Therefore, the Court argued that it was not important whether the allowances were held or not, but the very fact that they were not surrendered endangered the objective pursued by the scheme. In this sense, it did not consider the two situations as infringements of two different obligations, in the sense of a case law differentiating between primary and secondary obligations.

However, one could legitimately pose the question whether it seems problematic to penalise someone for something he did not do? As the Advocate General pointed out, it was not proven that the applicants in the case intended to circumvent the scheme, or whether this took place, since their trading accounts were blocked immediately afterwards. In this regard, it seems relevant to point out that according to the European Court of Human Rights (hereinafter: ECtHR) in order to be considered proportionate, the interference with a right (...) should correspond to the gravity of the infringement (...) rather than to the gravity of any presumed infringement which had not however been actually established'. ${ }^{161}$

It could be argued that the Court's arguments were rather selective, especially as it did not refer to the parts of the Memorandum mentioned above and in the AG's Opinion. This is particularly due to the nature of the proportionality test applied in the case, which does not provide for the "elaborated scheme of reasoning"162 when the Court acts deferentially to the legislative branch. In those cases, as explained by Lenaerts, ${ }^{163}$ a process-oriented review is a tool the Court could use to countervail its deferential stance. It would allow examining whether all factors were taken into consideration when fixing the fine. From the Memorandum, it is apparent that the penalty was designed to deter the operators from over-emitting. It was set taking into account only this type of wrongful behaviour. In this respect, it is interesting to observe the considerations of Advocate General Wathelet in a case concerning the proportionality of penalties, where he referred to the Court's case law in this respect:

${ }^{161}$ Case C-255/14 Robert Michal Chmielewski v Nemzeti Adó- és Vámhivatal Dél-alföldi Regionális Vám-és Pénzügyőri Főigazgatósága ECLI:EU:C:2015:308, Opinion of AG Wathelet, para 41 citing Ismayilov v Russia App no 30352/03 (ECtHR, 6 November 2008), para 38.

162 Patricia Popelier and Catherine Van De Heyning, 'Procedural Rationality: Giving Teeth to the Proportionality Analysis Patricia' (2013) 9 EuConst 230, 233.

163 Lenaerts (n 51). 
For example, in Billerud Karlsborg and Billerud Skärblacka (C-203/12, EU:C:2013:664), the Court held that the proportionality of a European Union measure cannot depend on retrospective assessment of its efficacy. Where, as in the present case, the EU legislature has to assess the future effects of legislation to be enacted although those effects cannot be accurately foreseen, its assessment is open to criticism only if it appears manifestly incorrect in the light of the information available to it at the time of the adoption of the legislation in question'. On that basis, the Court found that 'the penalty for excess emissions provided for by Directive 2003/87 cannot be considered to be contrary to the principle of proportionality on the ground that there is no possibility for the amount to be varied by a national court'. I note that in Louloudakis (C-262/99, EU:C:2001:407) the Court had held that flat-rate penalties which took no account of a number of criteria might 'prove to be disproportionate'. ${ }^{164}$

The Advocate General's considerations stress the difference between two Court rulings regarding the subject of the proportionality of penalties. These different approaches to the proportionality review have already been explained in the paper. In this sense, the Court's different approach in the Billerud case is justified by the discretionary power of the legislator and the Court's attentiveness in this regard. As mentioned above, the observations made by Lenaerts related to the process-oriented review could be relevant in this regard. As he points out, in Volker and Shecke the Court ruled that the relevant provisions of the Regulation in question were invalid as they went beyond what was necessary to achieve the desired outcome. Applying the proportionality principle in a procedural fashion, the Court concluded that the legislator did not take into account all options available and thus failed to observe measures which would secure the attainment of the objective in an equally effective way but which would at the same time be less restrictive to the fundamental rights in question. ${ }^{165}$

However, in this case, the challenged measures interfered with fundamental rights. Therefore, the proportionality analysis in the form of a process-oriented review was based on article 52(1) of the Charter. In the Billerud case, the proportionality review concerned the compliance of the discretionary policy measure with the principle of proportionality. The case was not presented in the light of a fundamental rights issue. However, it could have been, as the penalty in question interfered with the applicants' right to property, as will be shown in the next section of this paper.

\footnotetext{
164 AG Wathelet (n 161) paras 33-34.

165 Joined Cases C-92/09 and C-93/09 Volker und Markus Schecke GbR and Hartmut Eifert $v$ Land Hessen ECLI:EU:C:2010:662, paras 81-83 referred to by Lenaerts (n 51) 9-13.
} 


\section{The EU Charter of Fundamental Rights and the principle of proportionality}

The Court recognised early that 'respect for fundamental rights forms an integral part of the general principles of law protected by the Court of Justice'. ${ }^{166}$ The Court's landmark rulings in Nold ${ }^{167}$ and in Hauer ${ }^{168}$ recognised the right to property as part of the general principles of EU law. Since then, the Court has repeatedly held that:

[W] hile the right to property forms part of the general principles of Community law, it is not absolute but must be viewed in relation to its social function. Consequently, the exercise of the right to property may be restricted, provided that those restrictions in fact correspond to objectives of general interest pursued by the Community and do not constitute in relation to the aim pursued a disproportionate and intolerable interference, impairing the very substance of the rights guaranteed. ${ }^{169}$

As measures challenged on the ground of the right to property have mostly fallen within the scope of discretionary policies, the proportionality inquiry has been affected by the Court's conventional manifestly inappropriate test. ${ }^{170}$

The right to property is now codified in article 17 of the Charter. The protection of the right to property, and of all other rights recognised by the Charter, is guaranteed by article 52(1) of the Charter.

When comparing the proportionality test enshrined in article 52(1) of the Charter with the one established in the Court's case law as referred to above, one is left with different impressions as to the scope of the protection guaranteed. According to Craig, moving from 'impairing the substance of the right' as held in the Court's case law to 'respecting its essence' as written in article 52(1) indicates the changed position geared towards the higher protection of fundamental rights within the EU. ${ }^{171} \mathrm{He}$ further argues that the latter is only one of the conditions imposed by

\footnotetext{
${ }_{166}$ Internationale Handelsgesellschaft (n 13) para 4. As noted in Craig and de Búrca (n 32) 383, the first recognition of fundamental rights as general principles of EU law protected by the Court took place in the Case 26/69 Erich Stauder v City of Ulm - Sozialam ECLI:EU:C:1969:57, para 7.

${ }^{167}$ Case 4/73 J Nold, Kohlen- und Baustoffgroßhandlung $v$ Commission of the European Communities ECLI:EU:C:1974:51, paras 13-14.

168 Case 44/79 Liselotte Hauer v Land Rheinland-Pfalz [1979] ECLI:EU:C:1979:290, paras $15-17$

${ }^{169}$ Case C-293/97 The Queen $v$ Secretary of State for the Environment and Ministry of Agriculture, Fisheries and Food, ex parte HA Standley and Others and DGD Metson and Others ECLI:EU:C:1999:215, para 54.

${ }^{170}$ Craig (n 22) 674.

171 ibid, 680.
} 
article 52(1), pursuant to which, even where the essence of the right is not affected, interference must still be in compliance with the principle of proportionality as mandated by the second sentence of the latter article. ${ }^{172}$

Somewhat different observations were made by Groussout and Pétursson. They argue that the essence test must be viewed by having in mind the non-absolute nature of the right. In this regard, it should not be regarded separately from the proportionality analysis, "but rather in the context of it'. ${ }^{173}$ In this sense, they argue, it shapes the intensity of the review.

However they also pointed out that in several cases concerning the Charter, the Court conducted a strict review of the EU measure challenged from the perspective of fundamental rights and did not refer to a manifestly inappropriate standard of review. ${ }^{174}$ On the other hand, in Schaible, ${ }^{175}$ despite mentioning a manifestly inappropriate standard of review, the Court conducted in-depth proportionality analyses. ${ }^{176}$

These cases have been perceived as delineating new developments in the Court's case law, in a similar sense as argued by Lenaerts, ${ }^{177}$ by imposing strict obligations upon the EU legislator whenever there is a possibility that fundamental rights are going to be affected. ${ }^{178}$ In these terms, it is also worth noting the special observations made by the Council Legal Service:

The information note on the Digital Rights judgment underlines that it confirms that the Court of Justice will not satisfy itself with anything less than a strict assessment of the proportionality and necessity of measures that constitute serious restrictions to fundamental rights, however legitimate the objectives pursued by the EU legislature'. ${ }^{179}$

\footnotetext{
172 ibid.

173 Xavier Groussout and Gunnar Pétursson, 'The EU Charter of Fundamental Rights Five Years On: The Emergence of a New Constitutional Framework?' in Sybe de Vries, Ulf Bernitz, Stephen Weatherill (eds), The EU Charter of Fundamental Rights as a Binding Instrument: Five Years Old and Growing (Hart Publishing Ltd 2015) 143.

174 ibid, 147-148 referring to Volker (n 165), Case C-283/ 11 Sky Österreich GmbHv Österreichischer Rundfunk ECLI:EU:C:2013:28, paras 50-68; Joined Cases C-293/12 and C-594/ 12 Digital Rights Ireland Ltd $v$ Minister for Communications, Marine and Natural Resources and Others and Kärntner Landesregierung and Others ECLI:EU:C:2014:238, paras 38-69.

175 Case C-101/12 Herbert Schaible v Land Baden-Württemberg ECLI:EU:C:2013:661, paras 48-75.

176 Groussout and Pétursson (n 173) 148.

177 See $\mathrm{n} 51$.

${ }^{178}$ Francesca Ferraro and Jesús Carmona (European Parliamentary Research Service), 'Fundamental Rights in the European Union: The Role of the Charter after the Lisbon Treaty' (2015) 19-23 <www.europarl.europa.eu/RegData/etudes/IDAN/2015/554168/ EPRS_IDA(2015)554168_EN.pdf> accessed 10 August 2017.

${ }^{179}$ Council, 'Implementation of the Charter of Fundamental Rights of the EU - Presidency
} 
Another aspect of article 52(1) of the Charter deserving attention concerns the 'provided for by law' requirement. This condition mandates the fulfilment of two requirements - firstly, the existence of the proper legal basis and, secondly, its foreseeability and accessibility. In this sense, the limitations to rights must be set by appropriate use of expressions, meaning:

That 'law' must, in effect, be 'adequately accessible and foreseeable, that is formulated with sufficient precision in order to enable the individual - if need be with appropriate advice - to regulate his conduct', to 'foresee its consequences for him', 'to foresee, to a degree that is reasonable in the circumstances, the consequences which a given action may entail'. ${ }^{180}$

This 'quality of law' condition is an expression of the principle of legal certainty. In this respect, it is not a novelty in the sense of its content. ${ }^{181}$ However, the fact that 'provided for by law' is now part of article $52(1)$ should encourage the Court to refer to it every time it applies article 52 (1). However, this does not seem to be the case. ${ }^{182}$

The right to property as enshrined in article 17(1) of the Charter, ${ }^{183}$ as well as in article 1 of Protocol No 1 to the European Convention on Human Rights ${ }^{184}$ (hereinafter: ECHR), guarantees protection in three respects:

(1) entitlement to the peaceful enjoyment of possessions;

(2) prohibition of the deprivation of possessions, subject to specified conditions; and

(3) the right of the state to control the use of property, subject to specified conditions. ${ }^{185}$

discussion paper' (2014) 11415, 2 <www.statewatch.org/news/2014/aug/eu-council-eucharter-implementation-11415-14.pdf> accessed 10 August 2017.

180 Case C-70/10 Scarlet Extended SA v Société belge des auteurs, compositeurs et éditeurs SCRL (SABAM) [2011] ECR I-11959, Opinion of AG Villalón, para 94.

181 ibid, para 67.

182 Groussout and Pétursson (n 173) 139.

183 'Everyone has the right to own, use, dispose of and bequeath his or her lawfully acquired possessions. No one may be deprived of his or her possessions, except in the public interest and in the cases and under the conditions provided for by law, subject to fair compensation being paid in good time for their loss. The use of property may be regulated by law in so far as is necessary for the general interest'. Art $17(2)$ of the Charter relates to the protection of intellectual property - 'Intellectual property shall be protected'.

${ }^{184}$ Convention for the Protection of Human Rights and Fundamental Freedoms (European Convention on Human Rights) Protocol to the Convention for the Protection of Human Rights and Fundamental Freedoms (Protocol No 1).

185 Anne Van Aaken, 'Direct Expropriation: Multi-Layered Legal Protection in Europe' in Iljoong Kim, Hojun Lee and Ilya Som (eds), Eminent Domain: A Comparative Perspective (CUP 2017) 89 . 
In order to claim infringement to the right to property, one must prove in what way the right to property has been breached. In this regard, in the following section focus will be placed on the breach of the right to property stemming from disproportionate penalties.

\subsection{Penalty for excess emissions from the perspective of the right to property}

In its ruling in Bosphorus, ${ }^{186}$ the Court held that 'any measure imposing sanctions has, by definition, consequences which affect the right to property and the freedom to pursue a trade or business' ${ }^{187}$

Reviewing the Billerud case from the fundamental rights perspective would also involve invoking the ECtHR's case law. According to article 52(3) of the Charter, the same meaning and scope should be given to the rights encompassed by the Charter which correspond to the same rights enshrined in the ECHR. In this sense, article 1 of Protocol 1 to the ECHR corresponds to article 17 of the Charter. In Mamidakis $v$ Greece, ${ }^{188}$ the ECtHR explained that fines had to be regarded as interference with the right to property as they deprived the affected persons of an element of their property, ie the sum of money they had to pay. It continued by explaining that although States had the right to 'enforce such laws as it deems necessary to control the use of property in accordance with the general interest or to secure the payment of taxes or other contributions or penalties', 189 there must be a proportional relation between the means used and the objective pursued. In this sense, the financial obligation arising from the payment of a penalty might undermine the proportionality requirement if it imposes an excessive burden on the person concerned or fundamentally affects his financial situation. ${ }^{190}$

It seems that the ECtHR case law in this regard focuses on proportionality in the narrow sense, according to which individuals should not bear excessive burdens for the sake of the realisation of the objectives pursued by relevant measures. The excess emissions penalty calculated in relation to the number of allowances missing and in this regard imposing a fine of EUR 100 per allowance not surrendered can lead to extremely high sums. In the case of the Billerud companies, the penalty which was calculated pursuant to EUR 40 per allowance not surrendered amounted

\footnotetext{
${ }^{186}$ Case C-84/95 Bosphorus Hava Yollari Turizm ve Ticaret AS v Minister for Transport, Energy and Communications and others ECLI:EU:C:1996:312.

187 ibid, para 22.

188 Mamidakis c Grèce Requête no 35533/04 (ECtHR, 11 January 2007).

189 Protocol No 1 (n 184) art 1; Mamidakis (n 188) para 44.

190 Mamidakis (n 188) para 45; see also Case C-501/11 P Schindler Holding Ltd and Others $v$ European Commission ECLI:EU:C:2013:248, Opinion of AG Kokott, para 212 referring to the ECtHR case law in this respect.
} 
to penalties of EUR 433,120 and EUR 1,697,320. If the penalties had been imposed in the second trading period, they would have amounted to EUR 1,082,800 and EUR 4,243,300. One must bear in mind that basing the penalty on the total amount of emissions produced in the relevant year, which was the case with the Billerud companies, leads to a significantly higher penalty than in a situation where the penalty would be applied to over-emitting operators, as the penalty would then be calculated only pursuant to emissions not covered by allowances. In simple terms, the penalty applied in the former case is at the same time higher but also farther from the ultimate objective of high protection of the environment. In those situations, the penalty encumbers the operator concerned to such an extent that it fundamentally impairs its financial situation.

Nevertheless, if the penalty, as an interference with the right to property, was subject to article 52(1) of the Charter, the examination of its compliance with the requirements provided therein would in a perfect case start with an analysis of whether the interference is provided for by law. Examining the excess emissions penalty against this requirement in the light of the observations made in the previous section, one could come to the conclusion that the wording of article 16(3) was not sufficiently clear and precise to be understood in a way the Court interpreted it. This is even more so when taking into account that the requirement of legal certainty must be observed all the more strictly in the case of rules liable to entail financial consequences, in order that those concerned may know precisely the extent of the obligations which they impose on them'. 191

One can firmly claim that the excess emissions penalty was open to two different interpretations. In this sense, the Court consistently held that if the wording of secondary EU law is open to more than one interpretation, preference should be given to the interpretation which renders the provision consistent with EU primary law. ${ }^{192}$ Taking into consideration the principle of proportionality and the principle of equality, as explained earlier in this paper, one could well argue that the penalty should have been interpreted as not applying to situations such as the one in the case of the Billerud companies.

Without questioning the suitability of the penalty, and moving onto the necessity requirement, having special regard to the process-oriented review in the light of the observations made above, it can be stated that the measure goes beyond what is necessary to achieve the objective of strict accounting. Justifying the necessity of the penalty from the perspective

\footnotetext{
${ }_{191}$ Case C-17/01 Finanzamt Sulingen $v$ Walter Sudholz ECLI:EU:C:2004:242, para 34.

192 Case C-135/93 Kingdom of Spain $v$ Commission of the European Communities ECLI:EU:C:1995:201, para 37.
} 
of the prevention of market manipulations and speculation seems problematic for the reasons already explained. In any case, a less restrictive measure pursuing the same objective of strict accounting could easily have been envisaged. An example can be found in the proposition made by Belgium in its position paper regarding the revision of the EU ETS for the next phase. In order to avoid the administrative burden concerning the surrendering of allowances, Belgium suggested allowing for the automated surrender of allowances. ${ }^{193}$ As stated, this proposal has no impact on the environmental integrity of the system: ${ }^{194}$

BE considers the excess emissions penalty of EUR 100 for each ton of carbon dioxide equivalent emitted for which the operator or aircraft operator has not surrendered allowances to be indeed dissuasive, but potentially disproportionate for all ETS installations. However, we do not question that penalties are needed. Furthermore, we are willing to examine how to avoid that companies could (unwillingly) miss their deadline for surrendering, for example by introducing automatic surrendering when sufficient allowances are available on the account. ${ }^{195}$

The same suggestion was made by the Dutch Emissions Authority. ${ }^{196}$ Adopting this suggestion would ensure that the application of the excess emissions penalty takes place only in situations of over-emitting. At the same time, the objective of strict accounting would be secured. This is not to say that the Court, if reviewing the penalty from the fundamental rights perspective, should propose the same suggestion, as it is not in its capacity to make legislative assessments, but it does say that clearly less intrusive measures are available. In this sense, it would have been possible for the Court to come to the conclusion that the legislator did not take all possible alternatives into consideration, in the same way as it did in Volker and Schecke.

\footnotetext{
193 'Upon request by the operator and until that operator waives the request, and under the condition that sufficient allowances are available on the operator holding account, the number of allowances equal to the total emissions from that installation during the preceding calendar year as verified in accordance with Article 15 will be surrendered automatically before the deadline.' Council of the European Union, 'Proposal for a Directive of the European Parliament and of the Council amending Directive 2003/87/EC to enhance cost-effective emission reductions and low-carbon investments - Policy debate = Delegations' contributions' (2016) 10237, 43 <http://data.consilium.europa.eu/doc/document/ ST-10237-2016-ADD-2/en/pdf> accessed 10 August 2017.

194 ibid, 42.

195 ibid, 18.

196 Steven Bank and others, 'A Simple and Effective EU ETS: Seven General Strategies and Numerous Practical Measures for Simplifying the European Union Emissions Trading System' (Dutch Emissions Authority, The Hague, 2015) 36.
} 


\section{Conclusion}

The EU ETS is at the heart of the EU climate change policy. It is part of a larger plan envisaged in the low-carbon economy roadmap, ${ }^{197}$ where the EU aspires to reduce greenhouse gas emissions from various sources by $80-95 \%$ by 2050 (compared to 1990). ${ }^{198}$ The transition to a low carbon society would result in many benefits for the EU. Apart from the environmental and related health benefits, the transition would 'make the EU less dependent on expensive imports of oil and gas'. ${ }^{199}$ Climate change regulation is a complex challenge that calls for a combined approach from different fields. Law is one of them. In this sense, Peeters emphasises the need for a careful evaluation of legislative regulation to ensure its compliance with a higher law, such as the principle of proportionality, equality and respect for fundamental rights. ${ }^{200}$ In this sense, she stresses the importance of an ex-post review of the measures already in place, such as those providing for enforcement mechanisms. In this regard, she refers to the Billerud case and the strict understanding of the excess emissions penalty by warning that further analysis is needed in order to evaluate whether this approach is reasonable. ${ }^{201}$

Suggestions made by Belgium in its proposition for the revision of the EU ETS, as well as research done by the Dutch Emissions Authority, are examples of the analysis made in this respect. However, reading the Commission's proposal for the amendments to the Directive, ${ }^{202}$ as well as the Council's ${ }^{203}$ and the Parliament's ${ }^{204}$ positions, it is apparent that the revision will not go in this direction.

\footnotetext{
197 Commission, 'Communication from the Commission to the European Parliament, the Council, the European Economic and Social Committee and the Committee of the Regions: A Roadmap for moving to a competitive low carbon economy in 2050' COM (2011) 112 final. 198 ibid.

199 Commission, 2050 low-carbon economy <https://ec.europa.eu/clima/policies/strategies/2050_en> accessed 10 August 2017; see also n 197.

${ }^{200}$ Marjan Peeters, 'The Law as an Instrument for Climate Protection: The Case of Integrated Approaches to Understanding Emissions Trading' in Ron Cörvers and others (eds), Sustainable Development Research at ICIS: Taking Stock and Looking Ahead (ICIS - Maastricht University 2016) 215.

201 ibid, 219.

202 Commission (n 113).

203 Council, 'Proposal for a Directive of the European Parliament and of the Council amending Directive 2003/87/EC to enhance cost-effective emission reductions and low-carbon investments - General approach' (2017) 6841 <http://data.consilium.europa.eu/doc/ document/ST-6841-2017-INIT/en/pdf> accessed 10 August 2017; Council, 'Proposal for a Directive of the European Parliament and of the Council amending Directive 2003/87/EC to enhance cost-effective emission reductions and low-carbon investments - Preparation for the trilogue' (2017) 9503 <http://data.consilium.europa.eu/doc/document/ST-95032017-INIT/en/pdf> accessed 10 August 2017.

${ }^{204}$ Parliament, 'Amendments adopted by the European Parliament on 15 February 2017 on the proposal for a directive of the European Parliament and of the Council amending Directive 2003/87 / EC to enhance cost-effective emission reductions and low-carbon investments' COM (2015) 337.
} 
It thus seems that the Court's ruling in Billerud was the final say on the compliance of the excess emissions penalty with the principle of proportionality. ${ }^{205}$

General principles, especially the principle of proportionality, are flexible tools enabling the Court to maintain at the same time 'flexibility and consistency' of its case law. ${ }^{206}$ In this sense, the Court can rely on the principle of proportionality in order to both invalidate and uphold the challenged measure. The final result will largely depend on the intensity of the Court's review. Accordingly, the manifestly inappropriate version of the proportionality test rarely results in a ruling against the challenged measure. ${ }^{207}$

Lenaerts argues that the Court's deferential approach towards legislative power 'in relation to substantive outcomes' of the legislation in question 'has been counterbalanced by a strict process-review'. ${ }^{208}$ The post-Charter era has indeed brought new developments in this regard. Noteworthy cases such as Volker and Schecke and Digital Rights Ireland have shown the Court's willingness to examine in a strict manner the compliance of the EU legislation with the proportionality principle and, in this respect, to narrow the legislator's discretion.

In Billerud, this was not the case. However, it could have been. A situation can be observed from different angles. The same goes for a case. A court can approach it from different perspectives, through different lenses. In a preliminary reference procedure, the Court is bound by the questions posed by national courts. In this sense, in the Billerud case, the Court was asked to interpret the objective of the excess emissions penalty and to review the penalty from the perspective of the proportionality principle. There was no reference to fundamental rights and the

\footnotetext{
205 After Billerud, the Court ruled on the excess emissions penalty on two more occasions: in Case C-148/14 Bundesrepublik Deutschland v Nordzucker AG ECLI:EU:C:2015:287 and in Case C-580/14 Sandra Bitterv Bundesrepublik Deutschland ECLI:EU:C:2015:835. However neither of these cases concerned the same factual situation as in Billerud. In Nordzucker, the Court ruled that the excess emissions penalty did not apply to operators understating emissions in their verified reports (article 16(3) of the Directive refers to the amount of emissions as stated in verified reports). In Bitter, the Court was aked whether the excess emissions penalty infringed the principle of proprtionality due to the drop in the price of the allowances, which are now many times cheaper than predicted. The Court answered in the negative. Moreover, it brought its decision in the form of a reasoned order. To this effect, see Ismer and von Hesler (n 44) 287-289, who argue that even in Billerud the Court should have taken into account the drop in the price of the allowances.

${ }^{206}$ Xavier Groussot and others, 'The Paradox of Human Rights Protection in Europe: Two Courts, One Goal?' in Oddny Mjoll Arnardóttir and Antoine Buyse (eds), Shifting Centres of Gravity in Human Rights Protection: Rethinking Relations Between the ECHR, EU and National Legal Orders (Routledge 2016) 14.

207 Schütze (n 20) 101.

${ }^{208}$ Lenaerts (n 51) 3.
} 
Charter. Accordingly, the Court approached the matter in a way that did not concern the applicant's right to property. Thus, on the one side, an important EU interest was at stake, while, on the other, the applicants' claims were not presented as those concerning their fundamental rights but rather as a general challenge to the EU legislator's policy choice. The Charter would have probably put more leverage on the applicants' side and would have enhanced the relevance of the proportionality principle in the case, and in this sense it would have induced the Court to play a more active role, especially in applying the proportionality principle in a 'procedural fashion'. At least, it would have called for more detailed reasoning. 